\title{
Estimation of Phenotypic and Genetic Parameters and Genetic Trend of Weights in the Weaning Phase (P205), Weight at one Year (P365), the Yearling (P505) in Nellore Cattle in the Northern Region and Under-Region Middle-North of Brazil
}

Mário Fernando de Assunção Sousa ${ }^{1}$, Raimundo Martins Filho², Severino Cavalcante de Sousa Júnior ${ }^{3}$, Wéverton José Lima Fonseca ${ }^{4}$, Gioto Ghiarone Terto e Sousa ${ }^{5}$, Carlos Syllas Monteiro Luz ${ }^{5}$, Cicero Pereira Barros Junior ${ }^{4}$, André Campêlo Araujo ${ }^{4} \&$ Johnny Iglesias Mendes Araújo ${ }^{4}$

${ }^{1} \mathrm{PhD}$ of Graduate Animal Science / CCA / UFPI

${ }^{2}$ Doctor, UNIDERM

${ }^{3}$ Teacher Assistant II Bioclimatology and Behavior and Animal Welfare

${ }^{4}$ Graduating in Animal Sciences - UFPI. Brazil, Piauí, Bom Jesus

${ }^{5}$ Master in Animal Science, Department of Animal Science - DZO / UFPI

Correspondence: Wéverton José Fonseca Lima, Undergraduate Course of Bachelor of Animal Science, Federal University of Piauí, Bom Jesus, PI64900-000, Brazil. Tel: 55-89-8107-3652. E-mail: wevertonsbz@yahoo.com

Received: March 21, 2013 Accepted: May 20, 2013 Online Published: July 15, 2013

doi:10.5539/jas.v5n8p50 URL: http://dx.doi.org/10.5539/jas.v5n8p50

\begin{abstract}
We studied 257 herds of 257 farms, totaling 79,051 observations in eight States of the Federation, which genetic and phenotypic parameters were estimated for the weights to 205 (P205), 365 (P365) and 550 days old (P550) of Nelore, included in the system of development Control by weight (CDP) conducted by the Brazilian Association of Zebu breeders $(\mathrm{ABCZ})$ and raised in the northern region and sub-region Means North. Estimates of variance components and genetic parameters were obtained by the MTDFREML application, which uses the methodology of the Restricted Maximum Likelihood Derivative Free with an animal model that considers as fixed the effects of the farm such as year, month of birth, and gender. The heredity for P205 was $0.13 \pm 0.02$ and for P365 was $0.18 \pm$ 0.05 , which may indicate little additional genetic variation for these characteristics. For P550 days the estimated heredity was $0.23 \pm 0.07$, considered average, what indicates that at this age it is possible to select for weight gain. The genetic, phenotypical and environmental likeness among the weights in different ages were: P205-P365 $=0.92$, 0.72 and $0.79 ; \mathrm{P} 205-\mathrm{P} 550=0.89,0.61$ and 0.87 and P365-550 $=0.98,0.80$ and 0.87 . The genetic tendency in P365, for direct effect was significant and positive equals $0.455 \mathrm{~kg}(\mathrm{P}<0.001)$. Genetic trends in P205, P365 and P550 for direct effect were significant and positive, equal to $0.272 \mathrm{~kg}(\mathrm{P}<0.001), 0.455 \mathrm{~kg}(\mathrm{P}<0.001)$ and $0.744 \mathrm{~kg}(\mathrm{P}$ $<0.001)$, respectively.
\end{abstract}

Keywords: growth, estimated development, genetic changes, zebu cattle

\section{Introduction}

Beef production in Brazil is characterized by extensive raising, and in this aspect the Zebu breeds and their cross-bred have stood out as the most efficient solution for this kind of system and its use has contributed to the development of livestock, not only meat production, but also production of milk. Although most of Brazilian beef, estimated at more than 220 million animals, concentrate in the Southeast and Midwest, which holds about $62 \%$ of the national herd (Ibge, 2003), other regions have a significant quantity of animals.

Among the improvement methods available to modify the genetic potential of the animals, the selection is that one in which, by choosing the parents that will breed the next generation, searches to increase the frequency of desirable genes in the population (Ferraz Filho, Ramos, \& Silva, 2002). After the introducing the selection program it is necessary to evaluate it periodically to verify their efficiency (Manson, 1999), as well as evaluate the genetic tendency throughout the time. 
In terms of selection, the genetic improvement depends on the knowledge of the heredity of characteristics that interest and likeness among them, for these genetic parameters allow the prediction of direct responses and similar to the selection and the definition of the most appropriate selection method. Thus, the genetic improvement depends on the proper use of genetic variation of the selected characteristics.

In this context, the heredity of a character expresses the rate of the total variance that is attributed to the average effects of the genes, which determine the degree of similarity among the relationship. According to (Falconer, 1987), the most important function of heredity in the genetic study of the metrical character is its power to predict, showing the confidence of the phenotypic value as a guide to the genetic value. In the author's opinion, only the phenotypic value of the individual can be directly measured, but it is the genetic value that determines its influence on the next generation.

Therefore, if the breeder chooses the individuals to cross according to their phenotypic values, the change in the characteristics of the population will be well succeeded and it can be predicted only through the knowledge of the likeness degree between the phenotypic and genetic value that is measured by heredity. (Santos, Gomes, \& Silva, 2005) analyzing 11,823 observations in Nellore's breed in Bahia, estimated the heredity for the weight in 365 (P365) and 550 (P550) days old, with respective values for direct and maternal heredity of 0.66 and 0.11 to P365 and 0.57 and 0.07 for P550, suggesting that the selection for both the weights will result in genetic progress, since the coefficients of direct heredity were of very high.

The coefficient of likeness of the environment does not represent exactly the interdependence only because of environmental factors, since the components of variance and (co) variance environment of the similar characteristics include effects of dominance, epistasis and effects of genotype-environment interaction. (Fridrich, Silva, \& Figueiredo, 2005), have studied the breed performance, the genetic and environmental factors related to weights at ages of 205 and 365 days in Nellore cattle from the five regions of Brazil and they have found that the estimative of genetic and phenotypical parameters varies a lot from one region to another.

The genetic and environmental likenesses are, frequently, very different in importance, and sometimes different in sign. A signal difference between these two likeness shows that the causes of genetic and environmental variation, affect the characters through different physiological mechanisms (Falconer, 1987).

(Santos, Gomes, \& Silva, 2005), analyzing 11,823 observations in Nellore cattle in Bahia, found that the genetic similarity between weight in 365 and weight in 550 days old, was high (0.64), meaning that there are $64 \%$ likelihood in similar answer favorable in P550, if the selection is achieved for P365. Currently, the livestock in the North and northeast of Brazil is composed basically by pure Zebu animals or cross-breed created in the pasture, specially for its great adaptation to soil and weather conditions. However, the rates of production in breeding these animals are low and have the lack of wide-ranging genetic improvement programs as one of the reasons (Pied, Malk, \& Son Lôbo, 2005).

The aim was to raise the estimates of the components of co-variance to allow the assessment of environmental and genetic parameters for weights of 205, 365 and 550 days of age, and to assess the genetic and phenotypic changes in the weights at 205, 365 and 550 days of age in order to provide data to adopt appropriate criteria to establish breeding programs specific to the northern region and sub-region of the Middle-North, Brazil.

\section{Material and Methods}

The data analyzed were obtained from the Brazilian Zebu Breeders Association (ABCZ) and refer to Nellore animals included in Weight Development control system (CDP). We studied herds of 257 farms, totaling 79,051 observations. The animals were raised on pasture in the northern region and under-region Middle-North of the country, comprising the States of Amazonas, Pará, Tocantins, Rondônia and Acre and the States of Piauí and Maranhão, respectively. Each three months the animals were weighed until the age of 18 months, beginning the weighing at birth done by the breeder and the others made by ABCZ technicians.

The data obtained by the CDP used to estimate biological and genetic parameters for the weights at 205 (P205), 365 (P365) and 550 days old (P550), was analyzed in the laboratory of Informatics Center of Agrarian Sciences of the Federal University from Piauí (UFPI/CCA). For the organization of contemporary groups (CG) it was considered four periods of birth: January to March, April to June, July to September and October to December. The GC had animals from the same sex, farm, period of birth and year of birth. We have eliminated all the records related to GC with less than five observations. The information on the offspring from mothers over the age of 18 years and less than two years were deleted from the database.

To obtain the estimates of the variances components we used the methodology of Restricted Maximum Likelihood Derivative Free (DFREML), in which we analyzed animal models multi-characterists, using the application 
Multiple Trait Derivativ Free Restricted Maximum Likelihood (MTDFREML), developed by (Boldman, Kriese,\& Van Vleck, 1995). We used two models: a complete one to estimate genetic parameters and a simple model to estimate additive genetic correlations.

The complete model included random genetic effects, direct and maternal, and permanent environment, in addition to the fixed effect of GC and (co) variable cow age at parturition (years), linear and quadratic effects, admitting the covariance between direct and maternal effects equal to zero $(a m=0)$, considering $Y=X+{ }_{1}$ to $Z+Z_{2} m+Z_{3} p+e$, with $\left(\sigma_{\mathrm{am}}=0\right)$, where $Y=$ characteristics observations vector; $X=$ incidence pattern of fixed effects; $\quad=$ vector of fixed effects; $Z_{1}=$ incidence pattern direct additive genetic effect of each animal; a = vector of random direct additive genetic effects; $Z_{2}=$ incidence pattern of genetic maternal additive effect of each animal; $m=$ vector of maternal additive genetic random effects; $Z_{3}=$ incidence pattern of permanent environment effect of the cow; $p=$ vector of random permanent environmental effects of cow; $\mathrm{e}=$ vector of random residual effects; $\sigma_{\mathrm{am}}=$ covariance between direct and maternal random effects. To follow the model it was taken on the following assumptions:

$$
E\left[\begin{array}{c}
y \\
a \\
m \\
p \\
e
\end{array}\right]=\left[\begin{array}{c}
X b \\
0 \\
0 \\
0 \\
0
\end{array}\right]
$$

$$
V A R=\left[\begin{array}{c}
a \\
m \\
p \\
e
\end{array}\right]=\left[\begin{array}{cccc}
A \sigma_{a}^{2} & 0 & 0 & 0 \\
0 & A \sigma_{m}^{2} & 0 & 0 \\
0 & 0 & I \sigma_{p}^{2} & 0 \\
0 & 0 & 0 & I \sigma_{e}^{2}
\end{array}\right]
$$

Where $\mathrm{A}=$ pattern of kinship; $\mathrm{I}=$ identity pattern; $\sigma_{a}^{2}=$ additive direct genetic variance; $\sigma_{m}^{2}=$ additive maternal genetic variance; $\sigma_{p}^{2}=$ variance of permanent environment; $\sigma_{e}^{2}=$ residual variance.

For the bivariate analyses, we have taken the following presuppositions:

$$
\begin{gathered}
E=\left[\begin{array}{l}
y_{1} \\
y_{2}
\end{array}\right]=\left[\begin{array}{l}
X_{1} b \\
X_{2} b
\end{array}\right] \mathrm{e} \\
V A R=\left[\begin{array}{l}
a_{1} \\
e_{1} \\
a_{2} \\
e_{2}
\end{array}\right]=\left[\begin{array}{cccc}
A \sigma_{a 1}^{2} & 0 & A \sigma_{a l a 2} & 0 \\
0 & I \sigma_{e 1}^{2} & 0 & I \sigma_{\text {ele2 }} \\
A \sigma_{a \mid a 2} & 0 & I \sigma_{a 2}^{2} & 0 \\
0 & I \sigma_{\text {ele2 }} & 0 & I \sigma_{e 2}^{2}
\end{array}\right]
\end{gathered}
$$

Being A = pattern of kinship; $\mathrm{I}=$ identity pattern; $\sigma_{a 1}^{2}=$ additive direct genetic variance forcharacteristic $1 ; \sigma_{a 2}^{2}$ $=$ additive direct genetic variance for characteristic $2 ; \sigma_{a 1 a 2}^{2}=$ additive genetic covariance between direct genetic effects for characteristics 1 and $2 ; \sigma_{e 1}^{2}=$ residual variance to characteristic $1 ; \sigma_{e 2}^{2}=$ residual variance for characteristic $2 ; \sigma_{e 1 e 2}^{2}=$ covariance between the residual effects for characteristics 1 and 2 .

Estimates of genetic, phenotypic and environmental trends for the characteristics were obtained by the average regression of the dependent variable (genetic values, weights observed and the GC's solution) divided by the year of birth by two methods: 1) Linear regression and, 2) Regression by articulated polynomials by using the estimator Spline.

\section{Results and Discussion}

The estimates of the additive genetic variances $\left({ }_{\text {the }} \sigma^{2}\right)$, oresidual $\left({ }_{\mathrm{r}}^{2} \sigma\right.$ ) and phenotypic $\left({ }_{\mathrm{f}}^{2}\right)$ and of direct heredity (h 2) and maternal heredity $\left(\mathrm{h}^{2}\right.$ ) for the weights at 205,365 and 550 days old can be seen in Table 1 .

Table 1. Estimates of addictive genetic $\left(\mathrm{a}_{\mathrm{a}}^{2}\right)$, residual $\left(\mathrm{r}_{\mathrm{r}}^{2}\right)$ and phenotypic $\left(\mathrm{f}_{\mathrm{f}}^{2}\right)$ variances and of direct heredity $\left(\mathrm{h}^{2}\right)$ and maternal heredity $\left(\mathrm{hm}^{2}\right)$, with respective standart-error, for weights at 205 (W205), 365 (W365) and 550 (W550) days old

\begin{tabular}{lllllll}
\hline Weights & $\sigma \mathrm{a}^{2}$ & $\sigma \mathrm{p}^{2}$ & $\sigma \mathrm{r}^{2}$ & $\sigma \mathrm{f}^{2}$ & $\mathrm{~h}^{2}$ & $\mathrm{~h}_{\mathrm{m}}$ \\
\hline (W205) & 73,80 & 54,98 & 404,62 & 576,57 & $0,13 \pm 0,02$ & $0,07 \pm 0,01$ \\
(W365) & 213,53 & 95,74 & 834,99 & 1211,67 & $0,18 \pm 0,05$ & $0,06 \pm 0,02$ \\
(W550) & 508 & 85,05 & 1506,33 & 2220,77 & $0,23 \pm 0,07$ & $0,05 \pm 0,01$ \\
\hline
\end{tabular}


The estimated values for the additive genetic variances were much lower than those related to phenotypic and residual variances indicating that the low genetic variability in the studied herds, is probably due to the prolonged length of stay of breeders and patterns in these herds. Most of the reproductive is coming from the own herd, being used in natural breed. On the other hand, the little use of artificial insemination, limits the possibility of using the animals from other regions of the country.

The additive genetic variance was estimated as lower importance, especially for weight at 205 days and their contribution to the phenotypic variance, at that age, was very low. There has been a rise in the values of the additive variance as the ages of the animals grow. The components of phenotypic variances were different for the three weights, with increase related to the advanced ages (P365 and P550), indicating that, after the weaning, when most of them depend on themselves for food, the animals are more influenced by environmental factors.

The reduced heredity for weight at weaning phase (205 days), indicates little additive genetic contribution, meaning that most of the variation in the characteristics is due to environmental differences among the individuals. The value obtained was less than that reported by Ferraz Filho, Ramos, and Silva (2002) $-0.20 \pm 0.03$-to the Tababuã breed. The estimates of heredity for P365 indicate that there are reasonable additive genetic variation for this characteristic in the herds studied. Thus, the changes in weights is probable at 365 days old by direct selection.

For P550, the value found for heredity estimate $(0.23 \pm 0.07)$, must be considered as average indicating that at this age it is possible to make a selection for weight gain, because of the influence of additive genetic factors for this characteristic. A similar result was found by Ferraz Filho, Ramos, and Silva (2002). To Tabapuã breed (0.24 \pm 0.03 ). However, in the literature we can observe a great comprehensiveness for heredity of this characteristic, from 0.09 Lôbo and Martins Filho (2000) up to 0.79 (Rosa, Scott, \& Nobre, 1985).

The maternal heredity was considered average and indicates the influence of maternal effect on the development of animals over the time. So, we emphasize the importance of selecting for patterns, cows with good maternal ability and within an ideal age for breeding. Fridrich, Silva, and Figueiredo (2005) estimated the heredity for the direct genetic effect of P205 and P365 in Nellore's breed, in different regions of the country, finding values of 0.01 (South), 0.16 (Southeast), 0.29 (Midwest), (North) 0.21 and 0.16 (Northeast), and of 0.05 (South), and 0.13 (Southeast), 0.29 (Midwest), 0.20 (North) and 0.06 (northeast), respectively. These values, exception of those obtained for the South region, are close to or superior to those found in this study, considering the P205. For P365, the values found by the authors are superior to the ones in this study in the Southeast, Midwest and North regions.

The heredity values were lower in the regions mentioned above, possibly because of the increased environmental variance that was proportionately larger than the direct genetic variance for these regions. The phenotypic, genetic and environmental correlations between the weights to the differentages are shown in Table 2 .

Table 2. Correlations estimatites genetic, phenotypic and environmental of for body weights at 205 (W205), 365 (W365) and 550 (W550) days of age

\begin{tabular}{llll}
\hline Weight & Rg & Ra & Rf \\
\hline W205-365 & 0,92 & 0,72 & 0,79 \\
W205-550 & 0,89 & 0,61 & 0,71 \\
W365-550 & 0,98 & 0,80 & 0,87 \\
\hline
\end{tabular}

Estimates of genetic correlations were high and positive between the weights at 205 (P205), 365 (P365) and 550 (P550) days old, indicating that most of the genes that influence the weight at a certain age, also influences the weight in ensuing ages, allowing to infer that the selection to any of the weights should make changes the same way as the others. This is important because it allows the animals to be selected sooner. In General, estimates of correlations are higher for adjacent weights and, as the ages distance, a great amount of these estimates reduce.

The genetic correlation between P205 and P365 was high (0.92), as well as between P205 and P550 (0.89), and even more, between P365 and P550 (0.98), meaning that there is high probability of favorable correlated response, between themselves, probably as a result of pleiotropic effects of genes that act in these characteristics, so that one can perform the selection at 205 days old, expecting that the animals selected will present the same answer at 365 and 550 days old. Similar results were obtained by Seo, Oliveira, and Lôbo (2003), who found genetic correlation equal to 0.93 between P120 and P550 and 0.96 between P455 and P550 for Nellore's breed, in different States in the Southeast and Northeast regions of the country. 
The estimate correlations between P205 and P550 were lower than between P365 and P550, recommending that the selection for P550 is performed at one year age. The genetic correlation between P365 and P550, with value of 0.98 , means that there are $98 \%$ chances of correlated response favorable in P550, if the selection is performed to P365, because there is a high pleiotropic effect of genes that influence in these characteristics. Mucari and Oliveira (2003), studying the Guzerá breed, in the State of MatoGrosso do Sul, found genetic correlations inferior to these mentioned characteristics. Sethi, Oliveira, and Lôbo (2003) found genetic correlations between P120 and P550 equal to 0.93 and between P455 and P550 equal to 0.96, to Nelore breed, in different States of the Southeast and Northeast regions of the country. Although these authors have not worked with P365, the genetic correlation values obtained by them, indicate similar conclusions to those obtained in this study, i.e., positive and high values.

The genetic correlations obtained were similar to those estimated for the same race, in the State of Ceará in the Northeast region by Lôbo and Martins Filho (2000), indicating that the selection to any of the characteristics should provide changes in the others, in the same way. However, these estimates have shown high standard errors, probably due to the reduction in the number of observations at advanced ages, which reflects in most unreliable estimates. The environmental correlations between P205, P365 and P550 indicate that the environmental effects favorable to the weight in a certain age also contribute to a raise in weight at other ages. The values for environmental correlations obtained in this study, probably can be attributed to different and adverse climatic conditions that occur over the months and the years, in the regions studied.

The genetic tendency is a measure that allows evaluating the change brought about by a selection process, in a certain characteristic, over the years (Pied, Malk, \& Son Lôbo, 2005). The genetic tendency in P205, for direct effect (Figure 1) was significant and positive equals $0.272 \mathrm{Kg} /$ year. In terms of annual genetic change, it represents $0.16 \%$ of the average observed of the population, accumulating reasonable genetic gain in the last 26 years of 7.07 $\mathrm{Kg}$ for direct effect. Thus, we noticed that there was a reasonable genetic gain and there was an evolution of the herd over the years.
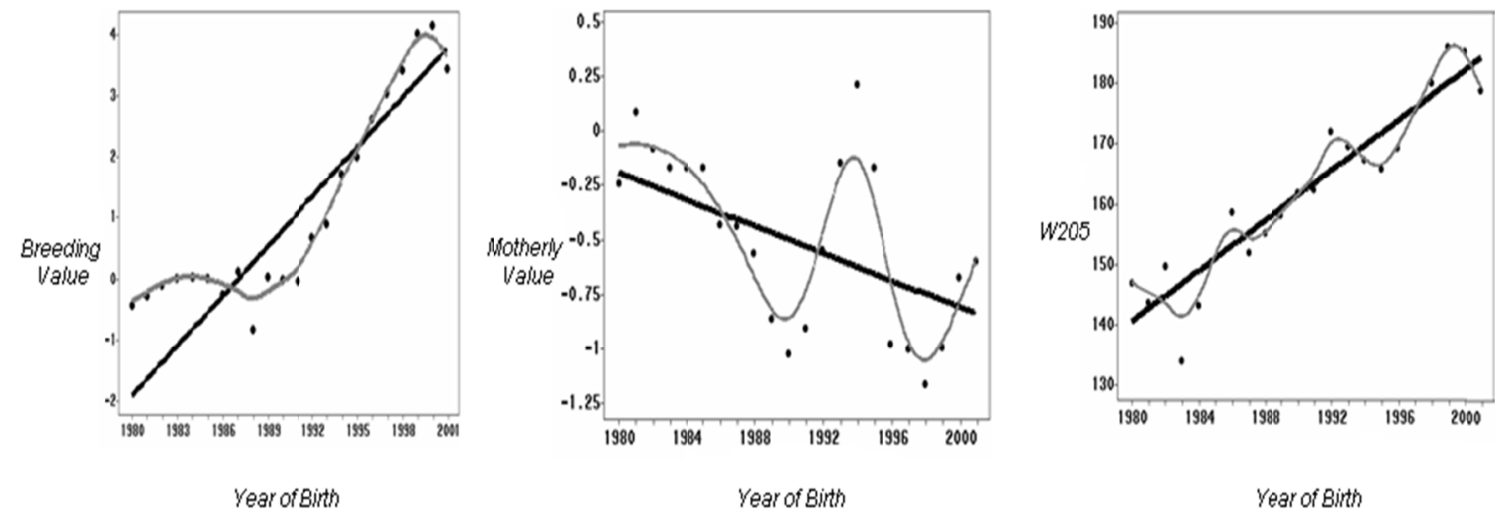

Figure 1. Genetic trends of the direct effect, motherly and fenotipic for 205 days

The genetic trend in P205, to maternal effect was not significant, being equal to $0.031 \mathrm{Kg}$. In terms of annual genetic change there is no genetic change accumulated by the maternal effect, meaning that there was no proper selection for maternal effect over the years. Similar results were reported by (Azevedo, 2003), studying trends in direct genetic cattle in Tabapuã breed throughout the Northeast. The phenotypic trend presented significant values showing an annual gain of $2.08 \mathrm{Kg} / \mathrm{year}$, reflecting a great evolution over the years.

The genetic tendency in P365, for direct effect (Figure 2) was significant and positive, equal to $0.455 \mathrm{Kg} /$ year. In terms of annual genetic change, this represents $0.20 \%$ of the average observed population, accumulating genetic gain in the last 26 years of $11.83 \mathrm{~kg}$ for direct effect. The genetic trend in P365, for maternal effect (Figure 2), was significant and equal to $0.252 \mathrm{~kg} /$ year. The phenotypic trend resulted in significant values showing an annual gain of $3.155 \mathrm{~kg}$ a year, which means a great evolution over the years (Figure 2). 

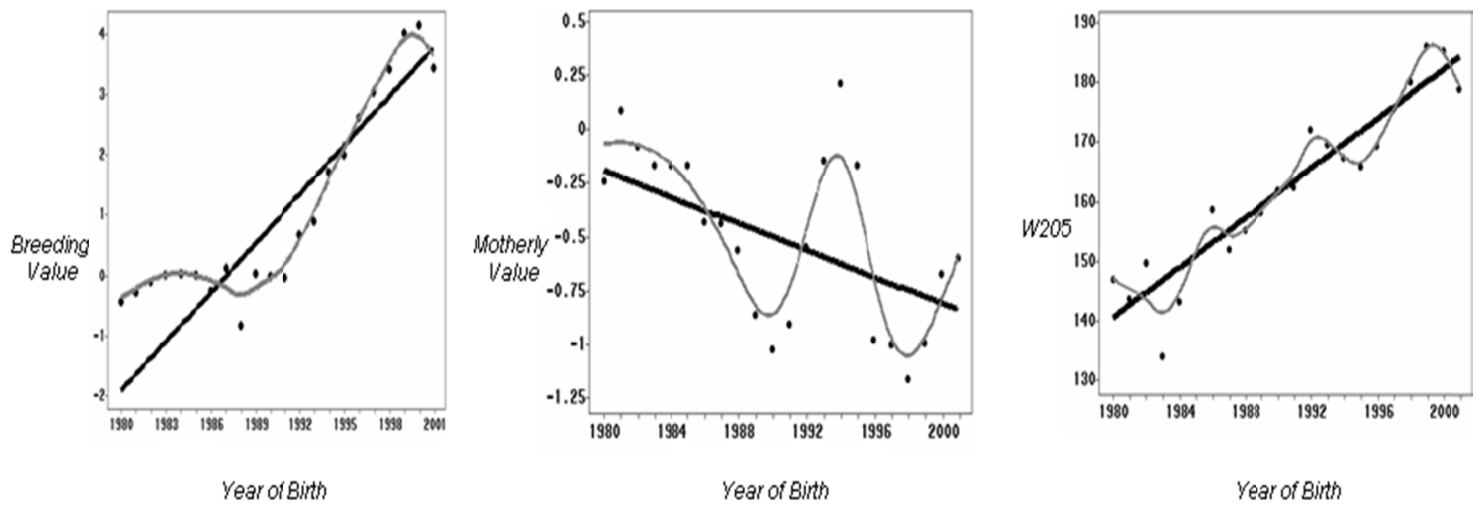

Figure 2. Genetic trends of the direct effect, motherly and fenotipc for 365 days

Results indicating low progress are not rare, as those reported by Ferraz Filho, Ramos, and Silva (2002) and (Azevedo, 2003). According to Silva, Rosa, and Gondo (2002), usually, phenotypic changes in the productive characteristics have on environment its greatest contribution. The genetic tendency in P550, for direct effect (Figure 3) was significant and positive equals $0.744 \mathrm{~kg} / \mathrm{year}$. In terms of annual genetic change, this represents $0.23 \%$ of the average observed population, accumulating genetic gain in the last 26 years of $19.34 \mathrm{Kg}$ for direct effect.

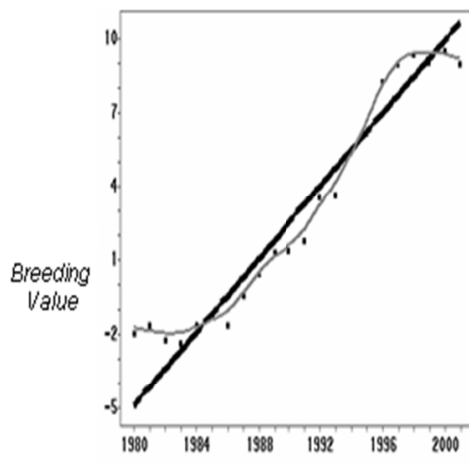

Year of Binth

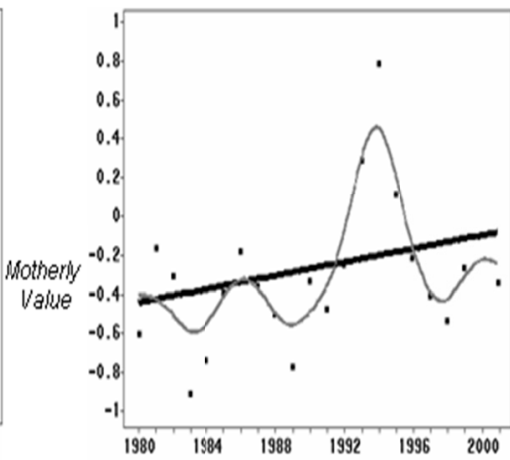

Year of Binth

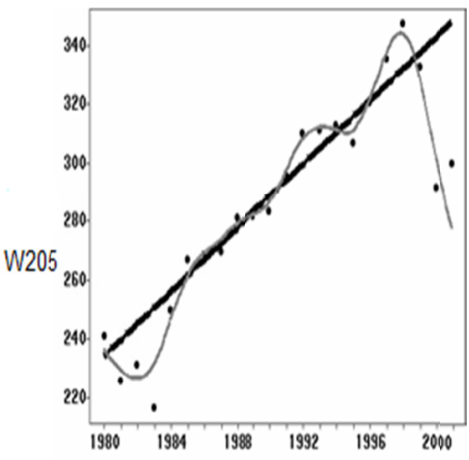

Year of Birth

Figure 3. Genetic trends of the direct effect, Motherly and fenotipc for 550 days

The genetic trend in P550, for maternal effect (Figure 3), equal to $0.172 \mathrm{~kg}$ a year, was not so significant. Thus, over the years there was no selection for maternal effect. It has to be considered that, at that age, there isn't much influence o the mother on growth. The phenotypic trend presented significant values with an annual gain of 5.440 $\mathrm{Kg}$ /year, which represents a great evolution over the years.

According to Biffani, Martins, and Son Giorgetti (1999), in typical livestock conditions in the Northeast, the breeders select the animals much by anatomical and racial characteristics than by productive performance. However, according to Pied, Malk, and Son Lôbo (2005), this trend has been decreasing over the years, as it can be seen in this paper, in which, it has occurred a small genetic gain over the years of study corroborating with these authors and also with Santos Gomes, and Silva (2005).

\section{Conclusions}

Animal selection for weight is more efficient at more advanced ages, because in these selections heredity estimates are higher. It is possible to anticipate the selection of animals to the weaning without damage to the yearling weight. There was little genetic gain over the analyzed years which points to the selection more focused on the productive performance. 


\section{Acknowledgements}

I would like to thank, first of all, God, by the strength and courage throughout this long journey. Thanks also to all the teachers who accompanied me during graduation.

\section{References}

Azevedo, D. M. M. R. (2003). Características reprodutivas e produtividade acumulada em fêmeas nelore nas regiões Norte e Nordeste do Brasil. Fortaleza Universidade Federal do Ceará, 2003. Tese (Doutorado em Zootecnia), Universidade Federal do Ceará, Fortaleza.

Biffani, S., Martins Filho, R., \& Giorgetti, A. (1999). Fatores ambientais e genéticos sobre o crescimento ao ano e ao sobreano de bovinos Nelore, criados no Nordeste do Brasil. Revista Brasileira de Zootecnia, 28(3), 468-473. http://dx.doi.org/10.1590/S1516-35981999000300005

Boldman, K. G., Kriese, L. A., \& Van Vleck, L. D. (1995). A manual for use of MTDFREML: a Set of Programs to Obtain Estimates of Variances and Covariances (DRAFT). Lincoln: Department of Agriculture, Agricultural Research Service.

Falconer, D. S. (1987). Introdução à Genética Quantitativa. Viçosa: UFV.

Ferraz Filho, P. B., Ramos, A. A., \& Silva, L. O. C. (2002). Herdabilidade e correlações genéticas, fenotípicas e ambientais para pesos em diferentes idades de bovinos da raça Tabapuã. Archives of Veterinary Science, 7(1), 65-69.

Fridrich, A. B., Silva, L. O. C., \& Figueiredo, G. R. (2005). Interação genótipo x ambiente e estimativa de parâmetros genéticos de características ponderais de bovinos Nelore. Arquivo Brasileiro de Medicina Veterinária e Zootecnia, 57(5), 663- 672. http://dx.doi.org/10.1590/S0102-09352005000500012

Ibge. (2003). Instituto Brasileiro De Geografia E Estatística. Anuário Estatístico do Brasil. Rio de Janeiro, 63.

Lôbo, R. N. B., \& Martins Filho, R. (2000). Genetic parameters for growth traits of zebu cattle in the semi-arid region of Brazil. Ciência Animal, 10(1), 7-12.

Malhado, C. H. M., Martins Filho, R., \& Lôbo, R. N. B. (2005). Tendência Genética sobre Características Relacionadas à Velocidade de Crescimento de Bovinos Nelore na Região Nordeste do Brasil. Revista Brasileira de Zootecnia, 34(1), 60-65. http://dx.doi.org/10.1590/S1516-35982005000100008

Mello, S. P. (1999). Tendência genética para pesos em um rebanho da raça Canchim: Jaboticabal: Faculdade de Ciências Agrária e Veterinárias, Universidade Estadual Paulista 1999. Dissertação (Mestrado em Zootecnia) Universidade Estadual Paulista.

Mucari, T. B., \& Oliveira, J. A. (2003). Análise genético-quantitativa de pesos aos 8, 12, 18 e 24 meses de idade em um rebanho da raça Guzerá. Revista Brasileira de Zootecnia, 32(6), 1604-1613 (Suplemento). http://dx.doi.org/10.1590/S1516-35982003000700009

Rosa, A. D. N., SILVA, L. D., \& Nobre, P. R. C. (1986). Avaliacao do desempenho de animais Nelore em controle de desenvolvimento ponderal no Estado de Mato Grosso do Sul, Brasil.

Santos, P. F., Gomes, C. M., \& Silva, L. O. C. (2005). Correlação genética, fenotípica e ambiental em características de crescimento de bovinos da raça Nelore, variedade Mocha. Archives of Veterinary Science, $10(2), 55-60$.

Silva, L. O. C., Rosa, A. N., \& Gondo, A. (2002). Estudo de tendências genéticas de características produtivas e reprodutivas na raça Tabapuã. In REUNIÃO ANUAL DA SOCIEDADE BRASILEIRA DE ZOOTECNIA, 39., Recife. Anais... Recife: SBZ, 2002. CD-ROM.

Siqueira, R. L. P. G., Oliveira, J. A., \& Lôbo, R. B. (2003). Análise da variabilidade genética aditiva de características de crescimento na raça Nelore. Rev. Bras. Zootec., 32(1), 99-105. http://dx.doi.org/10.1590/S1516-35982003000100013

\section{Copyrights}

Copyright for this article is retained by the author(s), with first publication rights granted to the journal.

This is an open-access article distributed under the terms and conditions of the Creative Commons Attribution license (http://creativecommons.org/licenses/by/3.0/). 